\title{
MOVING TOWARDS EVALUATION SUSTAINABLE UNIVERSAL HEALTH COVERAGE FINANCE POLICY: A COMPARISON STUDY BETWEEN INDONESIA AND THAILAND
}

\author{
Dyah Mutiarin (dyahmutiarin@umy.ac.id) \\ Amporn Tamronglak (amporntamrong@gmail.com ) \\ Suranto (suranto umy@yahoo.com ) \\ Awang Darumurti (awangdarumurti@yahoo.co.id ) \\ Sakir (mas.sakir@gmail.com ) \\ Department of Government Affairs and Administration \\ Universitas Muhammadiyah Yogyakarta

\section{EVALUATION OF SUSTAINABLE UNIVERSAL HEALTH COVERAGE FINANCE POLICY (UHC) : A COMPARISON STUDY BETWEEN INDONESIA AND THAILAND}

\begin{abstract}
This research is aimed to understand the evaluation study on Sustainable Universal Health Coverage Finance Policy both in Indonesia and Thailand. The results shows that there is tendency of overburden of public finance for both Indonesia and Thailand. Both of Thailand and Indonesia experienced the financial burden in implementing UHC Policy. The problem is more on the bulk amount of fund to cover the UHC from the annual budget which is accounted of the Annual National Gross Domestic Products (DGP), and become the burden for the National Budget allocated each year. Second, the quality of service is still in poor quality for Indonesian case and there is unequal distribution of government health facilities particularly in primary health care in Thailand. Third, the procedures of UHC for referral services is still complicated for the patients to get advance health care. The analytical approach of this study is derived from a qualitative research methods. In this research, the qualitative model will use the interview guide and focus discussion group to explore the information. FGD is conducted both in Indonesia and Thailand with the certain respondents and and key informan. Finally, this research also performing the procedures of triangulation to mean convergence among researchers. The research shows that Universal Health Coverage (UHC) Policy is an important health policy issue among ASEAN Countries. Indonesia and Thailand, needs to seek a sustainable policy model of UHC in financial model, improvement quality service and simplify referral service of current situation.
\end{abstract}

Keywords: Policy Evaluation-Policy Model - Universal Health Coverage 


\section{INTRODUCTION}

The implementation of Universal Health Coverage (UHC) both in Indonesia and Thailand began to take on a more definite shape for health service provision at large. Indonesia is one of several low- and middle-income countries aiming to improve their health financing systems and implement universal health coverage (UHC) so that all people can access quality health services without the risk of financial hardship ${ }^{1}$. Indonesia in 2014 marked a consecutive National Health Insurance as part of Universal Health Coverage (UHC) until now as its second year implementation. Even though the progress the Indonesian government has made since the rollout of the National Health Insurance Program (JKN) at the beginning of 2014, yet various issues remain such as health care infrastructure, health chain supply, drugs supply, sufficient and proper funding of the program ${ }^{2}$.

A research conducted by National Team for the Acceleration of Poverty Reduction $^{3}$, found that the implementation of JKN needs to be accompanied by major reform in the health- care system, those are : health-care service facilities, human resources in health, cost of health care rates, drugs supply, and strengthening the referral system. Base on data of Indonesian Ministry of Health, strengthening primary health-care service facilities is also essential for effective health services delivery. The number of primary health-care service facilities working with BPJS Kesehatan as of January 2014 was 15,861 , including 9,598 public health centres and 6,263 clinics, doctors or dentists. This could potentially increase to 23,768 between 2014 and 2019. However, both the quantity and the quality of primary health-care facilities need attention. The number of health-care facilities with referral services is adequate at the moment but these services will need to expand by 2019. As of 1 January 2014, 1,701 health-care service facilities were working in cooperation with BPJS Kesehatan. These included 533 government hospitals, 109 specialist and mental health-care hospitals, 104 national armed forces hospitals and 45 national police force hospitals. A further 504 facilities could potentially be added to this list, including 56 government hospitals, 42 private hospitals, 396 specialist and mental health-care hospitals and 10 national armed forces hospitals. The referral system also needs to become more efficient and effective in delivering health services (MoH 2012).

From the previous research of comparation evaluation on UHC implementation between Indonesia and Thailand in 2015, it is found that with the official estimates

\footnotetext{
${ }^{1}$ Institutional analysis of Indonesia's proposed road map to universal health coverage, Amanda Simmonds and Krishna Hort, 2013.

2 Universal healthcare coverage in Indonesia One year on, The Economist Intelligence Unit Limited 2015.

3 The Road To National Health Insurance (JKN), 2015, National Team for the Acceleration of Poverty Reduction/TNP2K.

${ }^{4}$ ibid, page 14.
} 
indicate that there are 76.4 million poor and near-poor beneficiaries of the 252.8 million total population in 2014, the National Health Agency/BPJS in Indonesia is managing formerly Jamkesmas to cover almost one third of the population. Based on the estimate that the government finance is targeted to cover 86.4 million with the PBI premium of Rp 19,225 per person per month, the central government's contribution to BPJS would equal to Rp 19.9 trillion. Since the government budget in 2014 was only Rp 44.9 trillion, it implies that almost half of the overall government health budget would be used to finance the BPJS. Then, the consequence is straightforward: the share for financing other areas of spending such as salaries and operating costs for centrally-financed hospitals, investments in improving supply and much-needed preventive and promotive interventions would have to be shrunk. The 2015 budget is allocating Rp 47.8 trillion.

While in Thailand, with the government's attempt to help all Thai citizens to have health security coverage, the number of registered population for UC scheme will be increased every year and as a consequence the cost of health care using tax-based compulsory finance will rise respectively. The money allocated for UC scheme has increased from 56,091 million baht in 2003 to 154,258 million baht, about three times when it was first started. As previously elaborated, as more people (about 73 percent of population) joined the UC scheme, it is the government's obligation to provide health care benefits as it promised during the election campaign in 2002. Though, looking at financial of UC Scheme, it seems to be alarming, but this money is only accounted for 1.1percent or 1.2 percent of the Annual National Gross Domestic Products (DGP), and only about 6percent of the National Budget allocated each year.

However, a closer look at the UC coverage from the data provided by NHSO, the amount of health coverage per person per year has increased more than 100percent from year 2002 to 2014, from 1202.40 Baht to 2895.09 Baht, due to the expansion of the coverage and the benefits package to include minor care to chronic diseases. The success story of Thailand should be given credits to all those behind the reform and a continuous developments of new ideas and the efficiency of funds management.

Both of Thailand and Indonesia experienced the financial burden in implementing UHC Policy. The problem is more on the bulk amount of fund to cover the UHC from the annual budget which is accounted of the Annual National Gross Domestic Products (DGP), and become the burden for the National Budget allocated each year. Second, the quality of service is still in poor quality for Indonesian case and there is unequal distribution of government health facilities particularly in primary health care in Thailand. Third, the procedures of UHC for referral services is still complicated for the patients to get advance health care.

With this background, in order to achieve the goal of this study, the policy model is utilized. Thus, by considering the Universal Health Coverage (UHC) Policy is an important health policy issue among ASEAN Countries, including Indonesia and Thailand. 


\section{B. LITERATURE REVIEW}

Study that had done by World Bank ${ }^{5}$ shown that Indonesia's system is characterized by a mix of public-private provision of services, with the public sector taking the dominant role, especially in rural areas and for secondary levels of care. However, private provision is increasing. Health service utilization rates are generally low nationally. About 14 percent of the population used outpatient care in the month before the 2010 Susenas survey. Around 60 percent of outpatient visits occurred at private facilities (typically clinics/midwives and nurses) and the rest at public facilities, mostly at primary care level. Susenas data also show that the better-off used private facilities for ambulatory services: 69.5 percent compared to 51.6 percent among the bottom three deciles. Public facilities continue to dominate inpatient care, except for the top three deciles, a larger proportion of which use private facilities for inpatient care.

Meanwhile Thailand, which has been implemented the Universal Coverage (UC) as part of Universal Health Coverage since 2002, has marked development of the health insurance system that can provide useful lessons for other lower- and middle-income countries. Universal coverage was achieved in Thailand in 2002, after the newly elected government introduced the "30-Baht for All Diseases Policy" in 2001. This 30-Baht policy extended health insurance coverage by establishing a Universal Coverage Scheme (UCS) to cover about 45 million Thais who were not already covered by the Civil Servant Medical Benefit Scheme (CSMBS) and the Social Security Scheme (SSS), by requiring only a 30-baht (about US\$1) copayment per visit. The policy also implemented major reform toward demand-side health care financing and strategic purchasing of health services, with closed-end payment mechanisms. Instead of providing budgetary funding to public sector health care providers based on its size, staff number, and historical performance, the 30- Baht Policy introduced a capitation payment that pays providers based on the number of people under their responsibility (contracting unit) ${ }^{6}$. Thailand's experience reforming its health care financing and coverage expansion can provide valuable lessons for many other low- and middle-income countries that are exploring options to improve the health coverage of their population.

However there are also some challenges of UHC implementation in Thailand. The UCS covers $75 \%$ of the Thai population, provides a comprehensive (and growing) package of services and deepening financial risk protection, and relies on general tax as its source of funding. In its first 10 years the scheme was adequately funded, aided greatly by GDP growth and strong political commitment.

In other hand, the path ahead for universal health coverage in Thailand should

\footnotetext{
${ }^{5}$ Universal Health Coverage for Inclusive and Sustainable Development, Country Summary Report for Indonesia, Puti Marzoeki, Ajay Tandon, Xiaolu Bi, and Eko Setyo Pambudi, Health, Nutrition and Population Global Practice World Bank Group, August 2014.

${ }^{6}$ Health Financing Reform in Thailand: Toward Universal Coverage under Fiscal Constraints, Piya Hanvoravongchai, The World Bank, Washington DC, January 2013.
} 
remain focused on equity, evidence, efficiency and good governance (Health Insurance System Research Office/HISRO, 2012). The study by HISRO (2012) stated that for ambulatory care in health centres, district hospitals, and provincial hospitals were pro poor while university hospitals seem to pro rich. This result can be implied that district health centres, district hospitals, and provincial hospitals performed well in terms of pro poor utilization. This might be due to the geographical proximity to rural population who are vastly poor. This pattern was consistent before and after UHC implementation meant that pro poor utilization was maintained. However, the pro rich pattern of university and private hospital might be explained that main customers of these hospitals are CSMBS and SSS patients who are better off than UC scheme patients. This pattern was similar in hospitalization of inpatients (Thammatach - aree, 2011).

Over all, Universal Health Coverage (UHC) in ASEAN countries has been a crucial issue of how a country provides health care policy for their citizens at large. The access to quality health service, provision of heath services, benefit to health scheme, and institutional design are amongst the features of UHC in its implementation (Lagomarsino, 2012; Simmonds and Hort, 2013). Indonesia and Thailand as developing countries in ASEAN experience UHC with the same rationality face the same problems in healthcare. The problem of inequality and poor quality still remains as the basic problem for both UHC in Indonesia and Thailand (Prakongsai et al. 2009; Limwatananon et al. 2009; Pitayarangsarit, 2012; Harimurti et al.2013; Road Map toward National Health Insurance, UC 2012-2019; Simmonds and Hort, 2013).

Public policy particularly in health sector does not only deal with individual or segmented interests, but it deals more with common objectives, public interests, or citizens at large. The proposed course of action that constitutes policy is then implemented through subsequent decisions and actions.

Reviewing health sector policy could not be separated from the nature of public policy itself. Grindle (1980 p. 11) says that the activities of implementation is strongly influenced by a number of factors (a) the content of policy (b) the context of policy implementation. Factors of policy content (content of policy) covers; (1) affected interests 2) type of benefit, (3) the desired extent changes, (4) location of decision making, (5) implementer programs and (6) affiliated resources. Whereas in the context of implementation the factors that influence are: (1) power, interests and strategies of the actors involved, (2) character-institutional characteristics in the regime, and (3) compliance and responsiveness.

Palmier, divides policy evaluation into four categories:

1. Planning and need Evolutions.

Includes assessment of the target population, the need now and in the future as well as existing resources.

2. Process evaluations

Evaluation of the implementation of the action, executing media programs and information systems. 
Proceeding ICOGISS 2019

Page 669-689. ISBN: 978-602-6 988-75-1

Web Jurnal Online: jurnal.unmuhjember.ac.id

By: Dyah Mutiarin; Amporn T.; Suranto; Awang D.; Sakir

Moving Towards Evaluation Sustainable Universal Health Coverage Finance

Policy: A Comparison Study Between Indonesia And Thailand

3. Impact evaluations

Evaluate impact of policies, whether expected or not, and the expansion of the program.

4. Efficiency evaluations

Evaluation of efficiency policies, which can be seen from the comparison with the cost advantage ( Leslie, 1987: 52)

With the aim to provide an assessment of the implementation program, in this assessment did not evaluate the overall phase of the policy but only one stage of its implementation (implementation evaluation).

Evaluation of the implementation according to Ripley is including the following:

1. Evaluation is reviewed to evaluate their processes

2. Implemented by adding questions to be answered in the perspective of what happened other than in compliance perspective.

3. Done with the evaluating aspects of the policy impacts that occur in the short term. (RJ Heru, 1997: 35)

Evaluation of the program performance consist of:

1. The relevance and the strategy of the program at large.

The focus will be on assessing to which extent the program is adressing the major problematic situation.

2. The effectiveness of the program.

It focus to which extent the program has been able to achieve its expected outputs and targets

3. The efficiency of the program.

It analyse to which extent the program has used its resources in an optimal way.

4. The impact of the program.

Impacts are changes at a higher level that are beyond the direct control of the program. It focus on changes in behavior within the groups and individuals with which the program had direct interaction.

5. The sustainability of the program.

It is to understand to which extent the program has already produced some impacts or is expected to do so in the future, given the constraining environment and influencing factors.

To know the results of a health sector policy on national social insurance, evaluations are undertaken to measure :

1. The existing policy framework and strategic plans for the UHC.

2. National health insurance budget distribution

3. Identify implementation systems and priorities, targets and standards of UHC .

4. The equity impacts of national social insurance policy. 


\section{METHODOLOGY OF THE STUDY}

This evaluation is based on the policy evaluation of health insurance in the selected areas. The followings are the steps that are taken in this study:

1. Most of the data in this study will be qualitative in nature. In qualitative, literature on methodology suggest that in qualitative research tradition, confidence or credibility is acquired by performing the procedures of triangulation (Denzin, 1970). Triangulation has also come to mean convergence among researchers (agreement between field notes of one investigator and observations of another) and convergence among theories. The instruments for qualitative approach will use interview guide and Focus Discussion Group.

2. Data using in this research will be primary data and secondary data. Primary data will be collected through depth interview and FGD both in Thailand and Indonesia. There are considerable constraints to obtain data from the primary sources, and in this way, secondary data sources are particularly important. Secondary data consist of all evidence in the forms of documents and records.

In order to achieve through the goal of this study, the policy model is utilized. To serve this goal, the scope of this research project has 5 phases of study:

\section{Phase 1:}

The 1st phase of the study provides a comparative analysis of the similarities and differences in the UHC of Indonesia and Thailand.

\section{Phase 2:}

The second phase is to explore the extent and policy related regarding gaps and problems of UHC by utilizing the result of first phase.

\section{Phase 3:}

The third phase is to evaluate policy in order to fill these gaps by decreasing or eliminating obstacles to the UHC system of Indonesia and Thailand.

\section{Phase 4:}

The fourth phase is to design draft of policies and strategy for improvement of UHC system regarding each urgent issue and over all in Indonesia and Thailand.

\section{Phase 5:}

The fifth phase is to provide result in improving the implementation model of UHC policy regarding as comparative analysis of policy in Indonesia and Thailand. 


\section{FINDINGS AND DISCUSSION \\ UHC PROFILES IN INDONESIA AND THAILAND}

\section{UHC Profile in Indonesia}

UHC in Indonesia well known as Jaminan Kesehatan Nasional (JKN) organized by National Board of Health Insurance (Badan Penyelenggara Jaminan Sosial KesehatanBPJS-Kesehatan). It was under the Law No. 40/2014 of the National Social Security System, on October 19, 2004. The legalization of the Law on National Social Security was also triggered by the Constitution of 1945 and its amendment in 2002 on Article 5 Verse (1), Article 20, Article 28H Verse (1), Verse (2), and Verse (3), along with Article 34 Verse (1) and Verse (2) which mandate to develop the National Social Security System. Until it was legalized and legislated, the Law on National Social Security System had been through a long process, from 2000 to October 19, 2004.

Legal Foundation of BPJS Kesehatan:

1. The Constitution of 1945

2. Law No. 40/2004 on National Social Security

3. Law No. 24/2011 on Social Security Provider

According to BPJS Kesehatan, members of BPJS Kesehatan is everyone, including foreigners who work for a minimum of 6 (six) months in Indonesia, which has been paying dues, including:

1. Recipient Contribution Health Insurance (PBI): the poor and people are not able to, with the determination of the participants in accordance with the law and regulation.

2. Not Receiving Aid Health Insurance Fee (Non-PBI), consisting of:

- Recipients Wage Workers and members of their families

Non Receiving Wage Workers and members of their families

- Non-workers and family members

UHC in Thailand is organized by The National Health Security Office or NHSO which was set up according to the 2002 National Health Security Act, with two governing national Boards, namely the National Health Security Board and the Health Service Standard and Quality Control Board. The National Health Security Board is responsible for policy setting and system development. In principle, the development of benefit packages, health care service standard, criteria for fund management and no-fault compensation as well as regulation frameworks for contracting providers are decided. As stipulated under Section 13 of the 2002 National Health Security Act, the National Health Security Board is chaired by the Minister of Public Health and consists of members from various public and private organizations.

NHSO is an autonomous organization acting as a secretariat office for both national boards to manage and ensure the attainment of universal coverage for all. The internal 
operation in NHSO is divided into two main sections, the head quarter and regional offices. The head quarter office consists of 15 bureaus responsible for policy and planning, system support as well as monitoring and evaluation. 13 regional NHS Offices take responsibility for administering and monitoring the fund management at the regional level. The regional offices will ensure that health security implementation is responding to the local health needs. In order to accomplish this goal, co-operation and participation of stakeholders in decision-making process and health-related activities are required. In each regional catchment's area, there is the number of population of 2.3 to 5 million.

\section{UHC Financial}

Budget for the national UHC coverage of Thai citizens in Thailand has been increased dramatically from $71.00 \%$ in FY2001 to $92.47 \%$ in FY2002 when implementing the UHC policy, and to $99.84 \%$ in FY2014. This coverage was not included stateless group living in Thailand, Thai citizens living aboard, and other foreigners. The number of Thai citizens who are eligible to enroll to the universal coverage scheme (UCS) but have not enrolled in FY2014 is 105,184 people $(0.16 \%$ of all population). However, the eligible non- registered group will be able to access to health services at any health facility registered to theUCS when they need; and, they can register to the UCS and select their contracting unit near their home. When classified into the main government health insurance schemes, i.e., the Civil Servant Medical Benefit Scheme (CSMBS), Social Security Scheme (SSS), and the Universal Coverage Scheme (UCS).

In Indonesia, JKN is conceived to provide better health coverage for all Indonesians, by extending insurance to the entire population, including large swathes of the population not previously covered by any public insurance schemes (The Economist Intelligent Unit, 2015).

The tariff for a particular kind of health service over a fixed period is calculated by dividing the total number of claims for that service by the total usage of health services. As with usage, adjustments are also needed in calculating the tariff for the health-care service. It is also necessary to keep in mind that inflation in the health sector is usually higher than general inflation.

The Payment methods consist of:

1. Primary health care providers: capitation

2. Secondary and tertiary health care providers: Ina-CBG's (Indonesian - Case Based Groups)

A single payer model places great responsibility on the purchaser to develop a payment system that is precise and fair. Indonesia boldly implemented a new prospective case-based payment system for Jamkesmas a few years ago called INA CBGs (for Indonesia Case-Based Groups). Using the INA CBGs, payments made to advanced level facilities were reformed through Ministry of Health regulation No. 692013 on the 
standard tariff for health services (Kumorotomo, 2015).

With the official estimates indicate that there are 76.4 million poor and near-poor beneficiaries of the 252.8 million total population in 2014, the BPJS is managing formerly Jamkesmas to cover almost one third of the population. Based on the estimate that the government finance is targeted to cover 86.4 million with the PBI premium of Rp 19,225 per person per month, the central government's contribution to BPJS would equal to Rp 19.9 trillion. Since the government budget in 2014 was only Rp 44.9 trillion, it implies that almost half of the overall government health budget would be used to finance the BPJS. Then, the consequence is straightforward: the share for financing other areas of spending such as salaries and operating costs for centrally-financed hospitals, investments in improving supply and much-needed preventive and promotive interventions would have to be shrunk. The 2015 budget is allocating Rp 47.8 trillion. (Kumorotomo, 2015).

The central government outlays to finance the premiums of 86.4 million poor and near-poor in 2014 are expected to be IDR 19.9 trillion ( 0.2\% of GDP), up from 6 trillion allocated for financing Jamkesmas in 2011 ( $\sim .1 \%$ of GDP). In addition to demand-side financing from the central government, additional supply-side financing from the central, provincial, and district governments will be needed to meet rising utilization rates as coverage expands. Indonesia's public spending on health was only around $0.9 \%$ of GDP in 2011, one of the lowest in the world (The Economist, Intelligent Unit, 2015).

In Thailand, with the government's attempt to help all Thai citizens to have health security coverage, the number of registered population for UC scheme will be increased every year and as a consequence the cost of health care using tax-based compulsory finance will rise respectively. The money allocated for UC scheme has increased from 56,091 million baht in 2003 to 154,258 million baht, about three times when it was first started. As previously elaborated, as more people (about 73 percent of population) joined the UC scheme, it is the government's obligation to provide health care benefits as it promised during the election campaign in 2002. Though, looking at financial of UC Scheme, it seems to be alarming, but this money is only accounted for 1.1 percent or 1.2 percent of the Annual National Gross Domestic Products (DGP), and only about 6percent of the National Budget allocated each year. However, a closer look at the UC coverage from the data provided by NHSO, the amount of health coverage per person per year has increased more than 100 percent from year 2002 to 2014, from 1202.40 Baht to $2895.09 \mathrm{Baht}$, due to the expansion of the coverage and the benefits package to include minor care to chronic diseases. The success story of Thailand should be given credits to all those behind the reform and a continuous developments of new ideas and the efficiency of funds management. The master plan for implementing JKN has been laid out by the Ministry of Health in the Road-Map for National Health Insurance 2012-2019, a complicated and ambitious policy for a country that is targeting universal coverage for 252.8 million people. According to the plan, the transformation of five existing schemes (Jamkesmas, Askes, Asabri, Jamsostek, and parts of Jamkesda) into a single scheme under BPJS should be completed in 2014. Then, the BPJS will manage the health 
insurance scheme for all people who have paid the premium and all for whom it has been paid. As explained earlier, the BPJS system will cover both the premium payers as well as poor individuals whose premium is paid by the government under the Premium Payment Assistance (PBI). Monthly premium and membership fee (4.5\% of salary) are made compulsory for all the workers, and the registration is to be completed in mid 2015. By 2017, all big and medium enterprises are expected to have the scheme. By 2018, the small enterprises are targeted to join. And by 2019 all Indonesian citizens and foreigners who work permanently in the country should be covered by the BPJS scheme.

The benefit packages to be covered by the BPJS include preventive and curative personal health care and rehabilitative services. Both medical and non-medical services such as ward accommodation and ambulance are also included. For the primary health care, the providers are Public Health Clinics, Private Clinics and general practitioners. And for the secondary and tertiary health care, the providers are both public and private hospitals. All the institutional arrangement has also been established under the master plan. Ministry of Health is responsible for setting regulations on health service delivery, tariff of services, medical prescriptions, and pharmaceuticals. Together with Ministry of Finance and the National Social Security Council, the ministry should also regulates monitors and evaluate the Universal Health Coverage (UHC) policy. The BPJS is responsible for registering health beneficiaries, administering membership, supervising health-care providers, and managing claims and complaints.

While in Thailand, according to Hanvoravongchai (2013), the National Health Security Office (NHSO), which serves as a state agency under the authority of the National Health Security Board (NHSB). According to the law, the board is authorized to prescribe the types and limits of Health service for (UCS) beneficiaries. The Board also appoints the NHSO secretary-general, who is in charge of NHSO operations. Under the law, the NHSO is responsible for the registration of beneficiaries and service providers, and administers the fund and pays the claims according to the regulations set out by the NHSB. In other hand, the path ahead for universal health coverage in Thailand should remain focused on equity, evidence, efficiency and good governance (Health Insurance System Research Office/HISRO, 2012). The study by HISRO (2012) stated that for ambulatory care in health centres, district hospitals, and provincial hospitals were pro poor while university hospitals seem to pro rich. This result can be implied that district health centres, district hospitals, and provincial hospitals performed well in terms of pro poor utilization. However, the pro rich pattern of university and private hospital might be explained that main customers of these hospitals are CSMBS and SSS patients who are better off than UC scheme patients. This pattern was similar in hospitalization of inpatients (Thammatach - aree, 2011).

The NHSO receives a UCS budget from the government based on the number of beneficiaries it covers and the capitation rate per beneficiary. Each year, the NHSO estimates the cost of service provision based on its unit cost studies and the number of beneficiaries it will cover. This cost per beneficiary (the capitation rate) is then submitted 
for approval by the government cabinet. The total budget based on the capitation rate is then submitted together with NHSO operating costs as part of the government budget to be approved by the parliament. Since its inception in 2002, the parliament has never revised the capitation rate approved by the Cabinet. However, the government could change the capitation figure requested by the NHSB, as happened in 2011, when the approved budget per capita is lower than the proposed capitation rate (Hanvoravongchai , 2013).

Further, the NHSO channels the funds to the contracted providers using several active purchasing mechanisms, with capitation and diagnosis-related groups (DRGs) the main payment methods. Payment for outpatient services is allocated based on the number of beneficiaries registered with a provider network (Contracting Unit for Primary Care, CUP). The capitation rate is adjusted by age composition, and the money is channeled directly to the CUP at the beginning of each budget year. For MOPH facilities, the amount transferred may be deducted for specific expenses, such as staff salary, at the central or provincial level depending on prior agreement between the NHSO and MOPH. Payment for inpatient services was allocated using case-based payment (following DRGs) under a global budget ceiling cap.

According to Hanvoravongchai , 2013, the main Actors and Fund Flows in the Thai Health System are described as below:

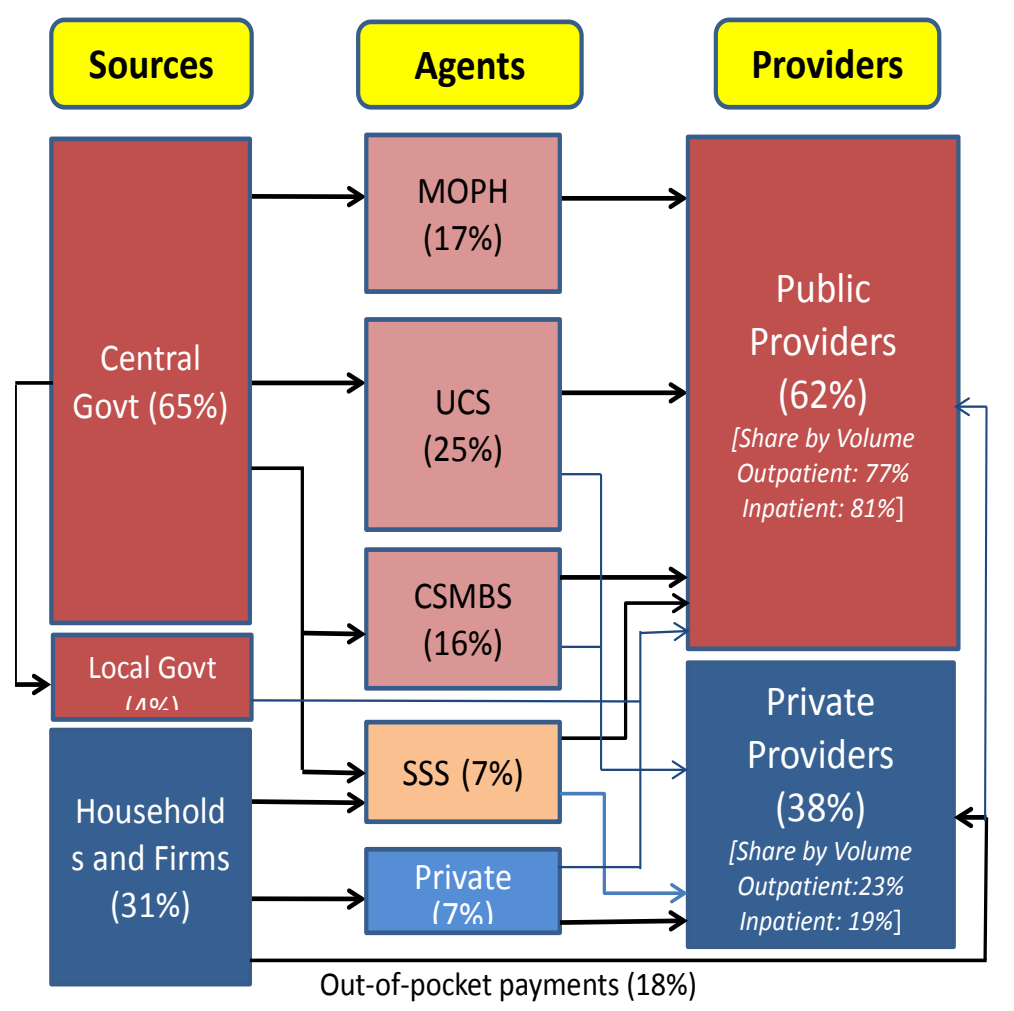

Sources: Data on fund flows are from National Health Accounts 2010 by the International Health Policy Program (IHPP)- Thailand. The diagram are non-MOPH 
public sector agents.

The Thai health financing system is financed mainly by general government revenue (tax-based financing). Wakatabe's et al (2016), showed that NHSO faces more difficult to convince the government in order to secure the capitation for preventive services due to less robust evidence than curative services. Therefore, the proportion of UC-PP has been marginalised from 15 to $10 \%$ of the UC budget by a higher increase in curative care. In 2013, 470 million US\$ (7.20 US\$ per capita) was allocated from government general taxes to these ser- vices for the entire population (65.4 million) (NHSO, 2013b). Under the prevention and promotion express- based payment (PPE) system, 248 million US\$ (3.8 US\$ per capita) was used for contracting units for primary care (CUPs) and primary care units (PCUs) provide service-based prevention (Evans et al., 2012). In 2013, NHSO also introduced performance-based financing (PBF) for 18 services (NHSO, 2013b). Seventy-five per cent of PPE is paid prospectively through age risk-adjusted capitation, while the remaining $25 \%$ is paid retrospectively if providers have achieved annual performance-based targets set by NHSO in consultation with MOPH.

While in Indonesia the scheme, Jaminan Kesehatan nasional (Natonal Health Insurance/JKN) was implemented by the newly-formed social security agency Badan Penyelenggara Jaminan Sosial Kesehatan (BPJS). It sought to improve the situation for citizens stuck in the middle of healthcare provision. Universal health coverage is defined as ensuring that all people have access to needed promotion, preventive, curative and rehabilitative health services, of sufficient quality to be effective, while also ensuring that people do not suffer financial hardship when paying for these services. Universal health coverage has therefore become a major goal for health reform in many countries and a priority objective of WHO. JKN member consist of 126 Millons members has been achieved by August 2014, with 18.355 contracted health facilities, consisting of 16804 primary care facilities and 1551 hospitals.

According to SEARO (2014), there are four main JKN issues raised in 2014 include:

1. Availability and equitable distribution of health services in outer islands to serve JKN members and overall quality of healthcare services ( Supply Site Readiness, WB 2014)

2. Provider payment: issues with long time laps for government primary care facilities in receiving capitation payment due to regulation on decentralization; and low tariff set in INA-CBG prospective payment.

3. Lack of JKN socialization activities for the people at large and coverage issues of people in the informal sectors.

4. Assurance of sustainable financing towards UHC.

In Indonesia, payments made to advanced level facilities were reformed through Ministry of Health regulation No. 69/2013 on the standard tariff for health services. These reforms were applied to level I and advanced level health-care service facilities under regulation 
No. 712013 on JKN health services. When Jamkesmas was first launched (2009-2010), payment of claims was based on the Indonesian Diagnoses-related Group (INA-DRG) but this was developed into the Indonesian case-based groups (hereafter referred to as INACBG) and has been used since 2011. As of 2014, it is not only used for patients who are PBIs but also for non-beneficiaries.

The INA-CBG payment model is the amount of the claim that BPJS Kesehatan pays advanced health-care facilities for their services, according to the diagnosed illnesses. The tariffs are determined and issued by a team known as the National Casemix Centre (NCC), under the Ministry of Health. Every year the team meets and processes data from hospitals and Jamkesmas to determine the tariffs and improve the methods used for calculating them. It allows greater transparency in managing and financing hospitals; - It provides an incentive for greater efficiency and better quality of service in hospitals, Also, case-based groups payments do not distinguish between high and low risk cases although the cost to the hospital is greater in high risk situations. This means that the case-based groups approach creates financial incentives for hospitals to avoid high-risk patients and this threatens the equity of access to health services ( TNP2K, 2015).

The most important challenge for creating prospective payments, which in effect reducing out-of-pocket transactions, is to establish and continuously maintain the database on health service. Table below describes the database of health service tariff in Indonesia that has been evolving recently in the national effort to attain universal coverage (Kumorotomo,2014).

\begin{tabular}{|c|l|l|}
\hline No. & \multicolumn{1}{|c|}{ Elements } & \multicolumn{1}{c|}{ INA-CBG (JKN, 2014) } \\
\hline 1 & Data coding & $6,000,000$ records \\
\hline 2 & Costing benchmark & 137 hospitals \\
\hline 3 & Contributors & $\begin{array}{l}\text { All classes in public and private } \\
\text { hospitals }\end{array}$ \\
\hline 4 & Case distribution & Normal \\
\hline 5 & Trimming method & IQR \\
\hline 6 & Tariff reference & Mean \\
\hline 7 & Number of case-base group & $1077+6$ Special CMG \\
\hline 8 & Tariff grouping & 6 \\
\hline 9 & Proportion of implemented tariff & $100 \%$ \\
\hline 10 & Clustering & 5 scales \\
\hline 11 & Medical care class & $3,2,1$ \\
\hline
\end{tabular}

Source: Wibowo, 2014 and Kumorotomo, 2015.

Financial sustainability of the JKN programme 
Proceeding ICOGISS 2019

Page 669-689. ISBN: 978-602-6 988-75-1

Web Jurnal Online: jurnal.unmuhjember.ac.id

By: Dyah Mutiarin; Amporn T.; Suranto; Awang D.; Sakir

Moving Towards Evaluation Sustainable Universal Health Coverage Finance

Policy: A Comparison Study Between Indonesia And Thailand

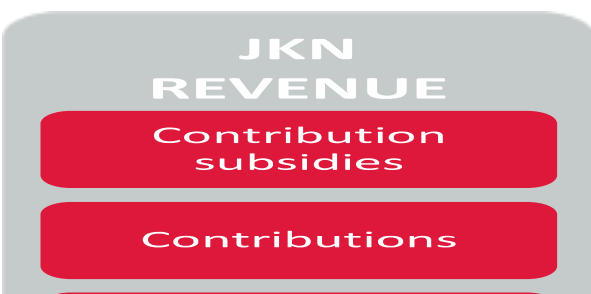

Investment interest

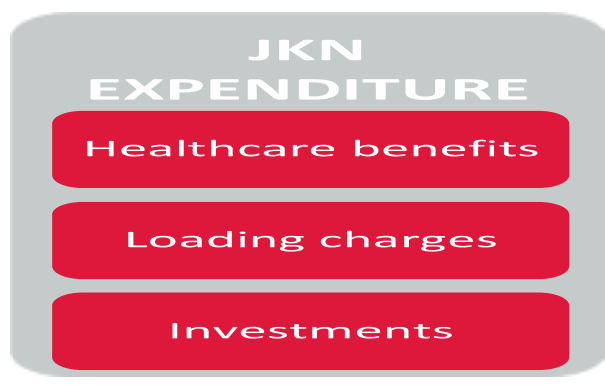

Source: Hidayat (2015).

The contributions for the poor and near-poor are paid by the government. In 2014, 86.4 million people were eligible for contribution assistance (known as PBI) and the GOI spent IDR 19.9 trillion (equivalent to US\$ 1.43 billion) financing PBI. In 2014 the JKN scheme exhibited a rather large financial deficit with a medical claim ratio of $115 \%$. This policy brief presents an assessment of the medium-term financial sustainability of JKN over the next five years. In 2014, the estimated costs PMPM were IDR 31,812, while the average contribution amounted to just to IDR 27,696. Dividing the costs by the contribution results in a claim ratio of $114.9 \%$. It is obvious that JKN contribution levels are inadequate to cover the health care services, resulting in a deficit of about $15 \%$ or IDR 4,116 PMPM. In future, the average JKN contribution could rise from IDR 27,696 PMPM to IDR 34,020 PMPM in 2019, an average increase of $4.6 \%$ a year. This projected rise is predicated on rising salary levels in the formal sector, a higher share of members from the informal sector, an increase of PBI subsidies and an assumedly better collection rate (Hidayat,2015). 
Financial state of JKN (IDR trillion) 2014-2015

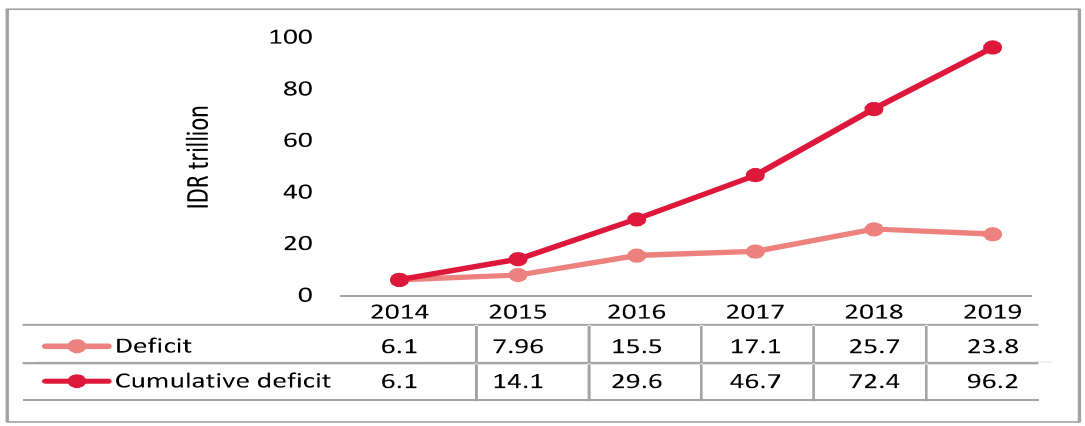

Source: Hidayat, 2015.

BPJS Kesehatan has been suffering from a deficit of claims it has paid against premiums it has received since late 2014. In 2014, the deficit stood at Rp 1.54 trillion, with $\mathrm{Rp} 42.6$ trillion paid out in claims and $\mathrm{Rp} 41.06$ trillion received in premiums. The country's total expenditure on health (TEH) has three-fold increase in the period 20052012, from IDR 28.4 trillion in 2005 to IDR 252.4 trillion in 2012; or from IDR 357.800 in 2005 to IDR 1.055 .100 in 2012 in terms of percapita per year. As \% of GDP, TEH has increased from $2.8 \%$ in 2005 to $3.1 \%$ in 2012. Further analysis found that the general government expenditure on health has increased around $10 \%$ share from $28.4 \%$ TEH in 2005 to $39.2 \% \mathrm{TEH}$ in 2012. Therefore, by percentage of TEH, the private expenditure has experienced $10 \%$ share reduction from $71.6 \% \mathrm{TEH}$ in 2005 to $60.8 \% \mathrm{TEH}$ in 2012 (Soewondo, 2014).

Under JKN, all citizens are now able to access a wide range of health services provided by public facilities, as well as services from a few private organisations that have opted to join the scheme as providers. JKN care aims to be comprehensive, covering treatment for everyday concerns such as flu through to open-heart surgery, dialysis and chemotherapy. Private insurance continues to play a role by providing for excess or additional coverage of services not included in JKN. 
Proceeding ICOGISS 2019

Page 669-689. ISBN: 978-602-6 988-75-1

Web Jurnal Online: jurnal.unmuhjember.ac.id

By: Dyah Mutiarin; Amporn T.; Suranto; Awang D.; Sakir

Moving Towards Evaluation Sustainable Universal Health Coverage Finance

Policy: A Comparison Study Between Indonesia And Thailand

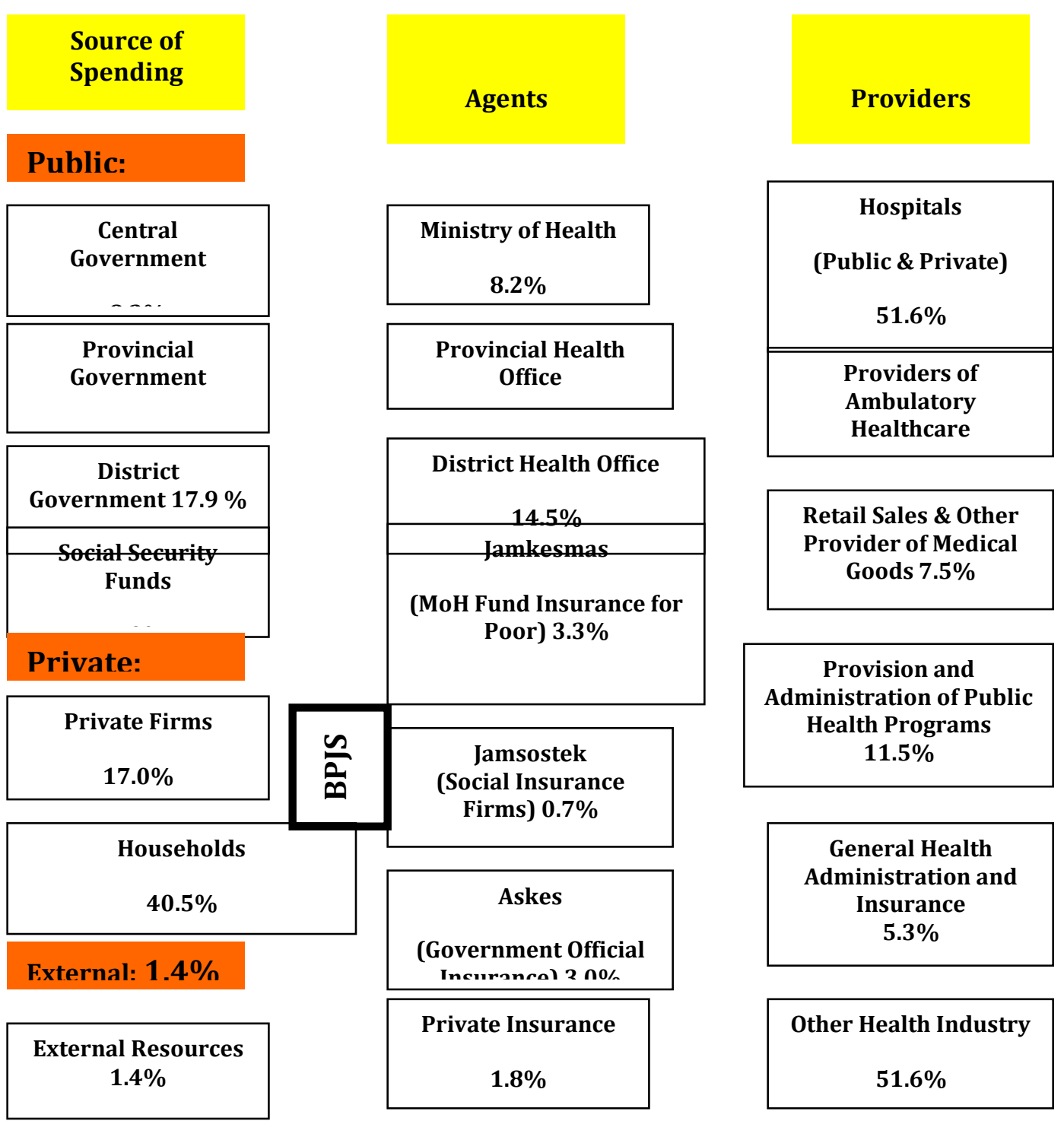

Health Financing and Provision in Indonesia

Source: Adapted from Soewondo et al, 2011; BPJS, 2014.

Figure above shows the general institutional arrangement for health financing and service delivery in Indonesia. Since 2014, the BPJS is aimed at integrating Jamkesmas, Jamsostek, Askes, and Jamkesda (which actually means insurance schemes managed by provincial and district governments). However, it turned out that most of Jamkesda schemes are currently managed by the provincial and district governments. There have been resistance from some of the provincial governors and district heads to fully integrate 
to the BPJS systems on the grounds that most beneficiaries at the local levels are in favor of the Jamkesda and they have been registered by the Jamkesda. As a compromise, the BPJS is applying the so-called "bridging" program for registration and for reimbursement of health services provided by public as well as private hospitals. Therefore, in many provinces and districts the Jamkesmas is complemented and even substituted by the Jamkesda (Kumorotomo, 2015).

Health financing for BPJS is set based on premiums from employers, employees and the government general revenues as outlined below. Payment of the individual contributions is an essential component in the design and management of the overall Social Health Insurance system, with estimates developed to be actuarially correct. Funding for the scheme is made up as follows:

1. Pooling of funds from contributions of individual members;

2. Subsidized contribution for those below the poverty line (PBI) from central and/or local government;

3. A structuring the contribution of individual members currently outside the insurance system.

\section{Conclusion}

Based on the Indonesian's JKN in Indonesia and UC implementation in Thailand, both of them experienced :

1. Thailand has one of the most complex health care systems in Asia. Prior to reform, there were about six different health benefits schemes, targeting different groups of people with different benefit packages, compare to Indonesia which has started UHC Policy in 2014, and it only has one scheme of UHC Policy with two different category of participants.

2. The Evaluation of UHC in Indonesia and Thailand results in varies remarks, but most of the results have higher remarks in Thailand.

3. For insurance coverage budget both are significantly increasing as well as its deficits. The governments of both countries need to address the constraints in providing benefits packages and payment mechanisms. The governments should building a strong pooled-fund for universal health coverage requires institutional arrangements that are responsive to financial efficiency, benefit equity, and continuous commitment giving services and high quality of health services to the poor. Finally, there is a need to balance between supply-side and demand side for services. 


\section{References:}

Akihito Watabe, Weranuch Wongwatanakul, Thaksaphon Thamarangsi, Phusit Prakongsai, and Motoyuki Yuasa, Analysis of health promotion and prevention financing mechanisms in Thailand, in Health Promotion International Advance Access published March 17, (2016), Health Promotion International, 2016, 1-9 doi: 10.1093/heapro/daw010.

Arikunto, Suharsimi, (2008). Action Research in the Classroom, Bumi Aksara, Jakarta,

Budi Hidayat, (2015), Financial Sustainability of the National Health Insurance in Indonesia: A First Year Review, DJSN \& GTZ.

Driscoll, David L, Afua Appiah-Yeboah, Philip S, Douglas J. Rupert, Merging Qualitative and Quantitative Data in Mixed Methods Research: How To and Why Not, University of Nebraska - Lincoln, (2007), Ecological and Environmental Anthropology, http://digitalcommons.unl.edu/icwdmeea.

Evans, TG. II. Chowdhury, AMR. III. Evans, DB. IV. Fidler, AH. V. Lindelow, M. VI. Mills, A. VII. Scheil-Adlung, (2012), Thailand's Universal Coverage Scheme: Achievements and Challenges. An independent assessment of the first 10 years (2001-2010). -

EY, (2015), The New Mandatory Health Insurance Scheme - Taking stock one year after the introduction, Ernst and Young (EY) Indonesia.

Grindle, Merilee S., (1980).Politics and Policy Implementation in the Third World, Princeton University Press, New Jersey,

Jurjus,Abdo,(2013).Thailand Health Care System: An Example of Universal Co verage, Human \& Health , No. 24 -- July

Kumorotomo, Wahyudi , (2015), Indonesian Health Policy Transition Towards Universal Coverage: A Preliminary Financial Analysis on The BPJS, Working Paper of Graduate Institute of International and Development StudiesUniversity of Geneva and Gadjah Mada University.

Limwattananon, S., V. Tangcharoensathien, et al. (2010)."Equity in maternal and child health in Thailand, 2010." Bulletin of the World Health Organization 88(6): 420-427.

Makarim, Rina, Taira S, Indonesia (2013): New Regulation on Public Health Insurance,

Mukti, Ali Gufron, (2012).Health Insurance Reform, Center of Health Finance Policy and Insurance Management, Faculty of Medicine, Universitas Gadjah Mada,

Pitayarangsarit, Siriwan, (2012).The Introduction of the universal coverage of health care policy in Thailand: Policy Responses, National Health Security Office, Bangkok, 
Piya Hanvoravongchai, (2013), UNICO Study Series 20 Health Financing Reform in Thailand: Toward Universal Coverage under Fiscal Constraints, The World Bank, Washington DC.

Prakongsai, P., N. Palmer, et al. "The Implications of benefit package design: the impact on poor Thai, 2009. households of excluding renal replacement therapy." Journal of International Development 21(2): 291-308.

President of the Republic of Indonesia. 2004. Law of the Republic of Indonesia Number 40 of 2004: National Social Security System (SSJN). National Secretariat, Republic of Indonesia, Jakarta.

President of the Republic of Indonesia. 2011. Law of the Republic of Indonesia Number 24 of 2011: Social Security Administration Agency (BPJS) National Secretariat, Republic of Indonesia, Jakarta.

President of the Republic of Indonesia. 2012. Presidential Regulation No. 101 of 2012: Health contribution beneficiaries. National Secretariat, Republic of Indonesia, Jakarta.

President of the Republic of Indonesia. 2013. Presidential Regulation No. 12 of 2013: Health insurance. National Secretariat, Republic of Indonesia, Jakarta.

Republic of Indonesia (RoI). 2012. Road Map toward National Health Insurance, 2012-2019. Jakarta: RoI.

Ripley, Randall B., Public Policies and Their Politics: An Introduction to the Techniques of Government Control, Norton \& Company Inc., New York, 1966

Road Map toward National Health Insurance-Universal Coverage 2012-2019 / Peta Jalan Menuju Jaminan Kesehatan Nasional 2012 - 2019, Kemenkokesra dll, Jakarta 2012.

Robert Sparrow, Asep Suryahadi Wenefrida Widyanti, Social Health Insurance for the Poor: Targeting and Impact of Indonesia's Askeskin Program, Working paper, The SMERU Research Institute Jakarta May 2010.

Shah, Anwar, Public Services Delivery, Edited by Anwar Shah, The International Bank for Reconstruction and Development / The World Bank 1818, 2005.

Simmonds, Amanda and Krishna Hort, (2014). Institutional analysis of Indonesia's proposed road map to universal health coverage, Nossal Institute for Global Health, University of Melbourne, 2013.

Soewondo P, et al, , Policy Brief Indonesia National Health Account

Subiyantoro, RJ Heru and Singgih Riphat (eds.), (2004).Kebijakan Fiskal: Pemikiran, Konsep dan Implementasi, Penerbit Kompas, Jakarta,

Thailand's Universal Coverage Scheme: Achievements and Challenges, An independent assessment of the first 10 years (2001-2010) Synthesis Report, (2012).Health Insurance System Research Office.

Thammatach-aree, Jadej, Health systems, public health programs, and social determinants of health, Thailand, Seminar Paper, World Health 
Proceeding ICOGISS 2019

Page 669-689. ISBN: 978-602-6 988-75-1

Web Jurnal Online: jurnal.unmuhjember.ac.id By: Dyah Mutiarin; Amporn T.; Suranto; Awang D.; Sakir Moving Towards Evaluation Sustainable Universal Health Coverage Finance

Policy: A Comparison Study Between Indonesia And Thailand

Organization for the World Conference on Social Determinants of Health, held 19-21 October 2011, in Rio de Janeiro, Brazil.

Universal Health Coverage 3, Gina Lagomarsino, Alice Garabrant, Atikah Adyas, Richard Muga, Nathaniel Otoo, Moving towards universal health coverage: health insurance reforms in nine developing countries in Africa and Asia, Universal Health Coverage 3, Vol 380 September 8, 2012.

World Bank's Sourcebook on "Social Accountability: Strengthening the Demand Side of Governance and Service Delivery" Social Accountability Sourcebook Chapter 4 Social Accountability In

The Health Sector.

TNP2K, 2015, The Road To National Health Insurance (JKN), National Team for the Acceleration of Poverty Reduction. 